\title{
Estimation of the Required Bio-fuels Substituting Petroleum-based Fuels in Vehicles in the Island of Crete, Greece
}

\author{
John Vourdoubas \\ Consultant Engineer, 107B, El. Venizelou str., 73132, Chania, Crete, Greece. \\ E-mail: ivourdoubas@gmail.com
}

Received: September 8, 2021 Accepted: October 1, $2021 \quad$ Published: October 12, 2021

doi:10.5296/jas.v9i4.18995 URL: https://doi.org/10.5296/jas.v9i4.18995

\begin{abstract}
The required bio-fuels for substituting petroleum-based fuels in vehicles in the island of Crete, Greece have been estimated. The quantities of gasoline and diesel oil currently used in vehicles in Crete as well as their GHG emissions have been calculated. The quantities of bio-ethanol and bio-diesel substituting 14\% of them, according to the EU goal for 2030, have been evaluated. The necessary land area for cultivating energy crops producing the required bio-fuels has been also calculated. The total quantity of gasoline and diesel oil used in vehicles in 2020 in Crete has been estimated at 273,231 tons while their $\mathrm{CO}_{2}$ emissions at 886,702 tons. The bio-ethanol required for substituting $14 \%$ of the annual gasoline consumption has been calculated at 29,709 tons while the bio-diesel required for substituting $14 \%$ of the annual diesel oil consumption at 24,802 tons. The necessary land area cultivated with sugar beet producing the abovementioned quantity of bio-ethanol has been estimated at 7,427 ha while the necessary land area cultivated with rape seed producing the abovementioned quantity of bio-diesel has been estimated at 24,802 ha. The overall necessary land area, at 32,229 ha, corresponds at 3.81\% of the total area in Crete. Energy crops have not been cultivated so far in Crete while the land availability is limited. It is proposed that apart from using bio-fuels in conventional vehicles equipped with ICEs different options for reducing GHG emissions in transportation, including the use of electric vehicles, should be considered in Crete.
\end{abstract}

Keywords: bio-ethanol, bio-diesel, Crete-Greece, diesel oil, energy crops, gasoline, GHG emissions, vehicle's transportation

\section{Introduction}

Mitigation of climate change is of paramount importance for avoiding major damages and 
catastrophes in the natural and human environment. EU has set the goal to de-carbonize its economy by 2050. Transportation utilizes mainly petroleum-based fuels and is currently responsible for significant atmospheric greenhouse gas (GHG) emissions. Reduction of GHG emissions in vehicle's transportation could be achieved either with the use of electric vehicles using green electricity and green $\mathrm{H}_{2}$ or with conventional vehicles equipped with internal combustion engines (ICEs) using bio-fuels. Carbon emissions can be reduced by substituting the petroleum-based fuels in conventional vehicles with bio-ethanol and bio-diesel. According to a recent EU directive the share of bio-fuels in the overall vehicles' fuels consumption by 2030 should be at $14 \%$. Bio-ethanol is produced in Europe mainly from sugar beet and wheat while bio-diesel from rape seed crops. Bio-fuels are not currently produced in Crete while the use of electric vehicles equipped with re-chargeable batteries or with fuel cells is limited so far. Increased use of bio-fuels in conventional vehicles does not require the creation of new infrastructure in Crete that is needed for electric vehicles related with batteries' re-charging stations. Our research is important since it indicates the quantities of bio-ethanol and bio-diesel required in vehicles transportation in Crete for achieving the EU target by 2030. It also indicates the necessary land area that is required for the cultivation of energy crops and the production of the abovementioned quantities of bio-fuels.

\section{Literature Survey}

\subsection{Yields in Bio-Fuels Production}

An estimation of bio-ethanol production from sugar beet and wheat crops in UK has been reported. The annual bio-ethanol yield from wheat crops has been calculated at 2.13 tons/ha while from sugar beet crops at 4.52 tons/ha (You may find the information at the end of References section:

http://www.esru.strath.ac.uk/EandE/Web_sites/02-03/biofuels/quant_bioethanol.htm). An estimation of bio-diesel production from oilseed rape in UK has been reported. The annual bio-diesel yield has been calculated at 1.16 tons/ha (You may find the information at the end of References section:

http://www.esru.strath.ac.uk/EandE/Web_sites/02-03/biofuels/quant_biodiesel.htm). The ethanol yield from sugar beet in the Netherlands has been estimated (Langeveld et al, 2008). The authors stated that the calculated annual ethanol yield was at 5.6-5.8 tons/ha. They also mentioned that the calculated yield was higher than the values reported elsewhere. The sugar beet cultivation in India for bio-ethanol production has been studied (Kumar Mall et al, 2021). The authors stated that the annual yield of bio-ethanol production from sugar beet varies between 4.15 to 5.21 tons/ha. The rapeseed-based bio-diesel production has been studied (Chen et al, 2011). The authors mentioned that countries like Germany have almost double yields at 1.87 tons/ha, in rapeseed production, compared to China. They also mentioned that the annual yield of bio-diesel production in China was estimated at 0.7 tons/ha. The bio-diesel production from rapeseed in Turkey has been estimated (Huseyin Ozturk, 2014). The author stated that the annual net bio-diesel yield was estimated at 0.806 tons/ha while the annual rape-seed yield at 2.14 tons/ha. Bio-fuel yields for different feed-stocks and countries have been reported (You may find the information at the end of References section: www.greenfacts.org). The yield of ethanol produced from sugar beet globally is at 4 tons/ha 
while for ethanol production from sugarcane in Brazil is at 4.33 tons/ha. The yield of bio-diesel produced from palm oil in Malaysia is at 4.17 tons/ha while for bio-diesel produced from soybean in USA is at 0.48 tons/ha.

\subsection{Bio-Fuels Production}

A report regarding the implications of bio-fuels produced in USA in water resources has been published (The National Academies, 2007). The report stated that the increased production of corn-based ethanol in USA is changing the national agricultural landscape and has impacts on the nation's water resources. There are also mentioned various policy measures that could help in the protection of water resources. The recent advances and the viability in bio-fuels production have been examined (Malode et al, 2021). The authors stated that elimination of various wastes can be combined with bio-energy generation using organic- based wastes for the production of green energy. The challenges and opportunities in biodiesel production have been studied (Rodionova et al, 2016). The authors studied the challenges and opportunities in third generation bio-fuels related with their production from cyanobacteria, microalgae and other microorganisms. They stated that although currently bio-fuels are not commercially competitive with fossil fuels their production in large scale is achievable and desirable. The bio-fuels production combined with oil prices and food security has been investigated (To et al, 2015). The authors developed a model combining global food prices, oil prices, GDP per capita and bio-fuels production. They stated that according to their model both higher oil prices and increased bio-fuels production have raised the price of food contributing to global poverty and chronic undernourishment. The production and use of bio-fuels has been studied (Beschkov, 2017). The author stated that biogas, bio-ethanol and bio-diesel can substitute fuels produced from oil. He also mentioned that bio-fuels can be used as raw materials for the production of chemicals that are currently produced from fossil fuels. The impact of bio-fuel production on food prices has been studied (Ajanoviv, 2010). The author stated that the feed-stocks currently used for the production of first generation bio-fuels are also used for food and animal feed production. He mentioned that bio-fuels production has no significant impacts on feedstock prices so far. The production of bio-fuels' by biomass gasification has been reviewed (Molino et al, 2018). The authors mentioned the biomass gasification technologies in second generation bio-fuels synthesized by syngas. They stated that purity of syngas is necessary for the production of second generation bio-fuels while optimization of the gasification process is also required. The use of carob and fried vegetable oils for bio-ethanol and bio-diesel production in Crete has been studied (Vourdoubas, 2002). The author mentioned that the carob fruit is rich in sugars while its cultivation is decreasing in Crete. He also stated that fried vegetable oils produced from the growing tourism industry could be used for bio-diesel production in the island.

\subsection{Environmental Impacts of Bio-Fuels and Climate Change}

A report concerning the use of bio-fuels for climate change mitigation has been published by the USA Department of Energy (Bio-fuels, A solution for climate change, 1999). The report stated that bio-fuels offer the most beneficial alternative for reducing GHG emissions in the transportation sector. Various low carbon alternatives from well to wheel for road traffic have 
been analyzed (Ramachandran et al, 2015). The authors investigated the use of electricity, $\mathrm{H}_{2}$ and bio-ethanol in transportation. They stated that battery electric vehicles (BEVs) using electricity generated by renewable energies (REs) and bio-ethanol based electric vehicles (EVs) with direct ethanol fuel cells had the best performance. They also mentioned that bio-ethanol has an additional advantage related with its alternative use in vehicles equipped with ICEs. The trade-offs in welfare and food security related with bio-fuels production in developing countries have been studied (Ewing et al, 2009). The authors stated that there is correlation between food insecurity and biomass usage that should be given consideration in policy design. They also mentioned that existing studies indicated that food prices are going to continue to rise in coming years in response to bio-fuels consumption targets adopted in USA and EU. The nexus among bio-fuels, GHG emissions and climate change has been reviewed (Bessou et al, 2010). The authors stated that bio-fuels still only contribute a marginal share in the global energy supply. They mentioned that second generation bio-fuels could help in achieving EU's $10 \%$ target while from the $\mathrm{CO}_{2}$ perspective the best mitigation pathway is to prevent emissions in transportation. Various bio-energy chains are suitable in different locations while positive externalities ought to be given economic values for better assessment of bio-fuels. The environmental sustainability of bio-fuels has been reviewed (Jeswani et al, 2020). The authors stated that first generation bio-fuels, if no land-use change is involved, have lower GHG emissions than fossil fuels. They mentioned that second generation bio-fuels have, in general, a greater potential to reduce emissions provided that there is no land-use change. Third generation bio-fuels have higher GHG emissions than fossil fuels. The performance of different bio-diesel blends against petroleum diesel has been studied (Mc Carthy et al, 2011). The authors compared the performance of two different bio-diesel blends having low energy content with petroleum diesel. They stated that the performance of bio-diesel was lower due to its lower energy content. The biomass to wheel efficiency in vehicles using bio-fuels has been calculated (Huang et al, 2011). The authors have analyzed 13 different scenarios comparing the efficiencies of various types of vehicles with vehicles equipped with ICEs using ethanol. They stated that the highest efficiency was achieved with a) a BEV powered with electricity generated from stationary fuel cells, and b) a vehicle equipped with a fuel cell and an on-board sugar to $\mathrm{H}_{2}$ bio-reformer. The efficiency of the two abovementioned vehicles was nearly four times higher than the vehicle equipped with an ICE using ethanol. A report on the performance of ethanol internal combustion engines has been published (Ethanol Internal Combustion Engines, 2010). It is stated that the typical efficiency, per unit energy, of vehicles running on blends of ethanol and gasoline is similar to vehicles using pure gasoline. The impact of bio-fuels use on climate change has been investigated (Khanna et al, 2011). The authors stated that according to recent studies GHGs emissions released from indirect land use changes could more than offset the direct GHG savings attributed to bio-fuels production and replacement of fossil fuels. This fact creates a "carbon depth" with a long payback period. The target share of renewable energy used in transportation in Europe has been increased at 14\% by 2030 (EU Directive 2018/2001, 2018). This value is higher than the old goal at $10 \%$ set for 2020 . It has been estimated that the share of renewable energies in transportation in Europe in 2019 was at $8.4 \%$ below the target set for 2020 at $10 \%$. A report on energy and GHG balance of bio-fuels in Europe has 
been published (Energy and Greenhouse gas balance of bio-fuels for Europe - an update, 2002). The report stated that when rape seed methyl ester (RME) substituted diesel oil the energy savings were at $47 \%$ while when ethanol produced from sugar beet substituted gasoline the energy savings were at $17 \%$. It is also mentioned that when ethanol produced from sugar beet substituted gasoline the GHG savings were at $16 \%$ while when RME substituted diesel oil GHG savings were at 53\%. The international trade of bio-fuels has been reviewed (Zah et al, 2009). The authors stated that since various countries try to comply with the goals set they import bio-fuels from other countries. This has a major impact on vegetable oil and animal feed markets as well as on global land use change. They also mentioned that there is a strong link between bio-fuels production and the global food market. A white paper regarding the emissions from bio-ethanol and bio-diesel compared with the petroleum alternatives has been published (University of Minesota, 2010). The report stated that E85 causes both positive and negative changes in emissions compared to gasoline. E10 and BD20 in general exhibit smaller changes in emissions compared to E85. The electrification of the transportation sector in the island of Crete, Greece has been studied (Vourdoubas, 2018). The author stated that if all the existing conventional vehicles equipped with ICEs in Crete will be replaced by electric vehicles the annual electricity requirements for re-charging their batteries would be at 1,092,568 to 1,311,077 $\mathrm{MWh}$ depending on the type of batteries. The green electricity required for electrolytic $\mathrm{H}_{2}$ production powering fuel cell-based electric vehicles in Crete has been estimated (Vourdoubas, 2021). The author stated that the annual electricity requirements for electrolytic production of the necessary $\mathrm{H}_{2}$ is at 3,826,563 $\mathrm{MWh}$. $\mathrm{He}$ estimated the annual $\mathrm{H}_{2}$ requirements for powering the electric vehicles equipped with fuel cells and replacing all the existing conventional vehicles in the island at 53,037 tons $\mathrm{H}_{2}$. The yield of bio-ethanol production from sugar beet in various countries is presented in table 1 while the yield of bio-diesel production from rape seed in table 2.

Table 1. Yield in bio-ethanol production from sugar beet

\begin{tabular}{lll}
\hline Country & Annual yield of bio-ethanol (tons/ha) & Source \\
\hline U.K. & 4.52 & 1 \\
Netherlands & $5.6-5.8$ & 3 \\
India & $4.15-5.21$ & 4 \\
Various countries & $3.96-5.28$ & 13 \\
Globally & 3.99 & 28 \\
\hline
\end{tabular}

Source: various authors 
Table 2. Yield in bio-diesel production from rape seed

\begin{tabular}{lll}
\hline Country & Annual yield of bio-diesel (tons/ha) & Source \\
\hline U.K. & 1.16 & 2 \\
China & 0.70 & 5 \\
Turkey & 0.81 & 6 \\
\hline
\end{tabular}

Source: various authors

Aims of the current research are:

a) To estimate the current quantities of conventional fuels used in vehicles in Crete as well as their carbon emissions,

b) To estimate the quantities of bio-fuels that could substitute the petroleum-based fuels in vehicles in Crete according the EU goal for 2030, and

c) To estimate the necessary land area for cultivating beet sugar and rape seed crops producing the required bio-ethanol and bio-diesel in vehicles in Crete

Initially the literature review is presented followed by the estimation of petroleum-based fuels' consumption in Crete as well as their carbon emissions. After that the required quantities of bio-ethanol and bio-diesel substituting $14 \%$ of the petroleum-based fuels used in conventional vehicles have been calculated as well as the necessary land area for cultivating the energy crops. The study ends with the discussion of the findings and the conclusions drawn.

\section{Consumption of Petroleum-based Fuels in Vehicles in Crete and their Carbon Emissions}

The majority of vehicles in Crete are equipped with internal combustion engines (ICEs) fueled with gasoline and diesel oil. Few of them are using LPG while only the last 2-3 years consumers have started to buy electric vehicles (BEVs) with re-chargeable batteries. Their capital cost is partly subsidized by the government. Electric vehicles equipped with fuel cells are not used currently in Crete. The current number of vehicles in Crete is presented in table 3.

Table 3. Number of vehicles in Crete (2020)

\begin{tabular}{ll}
\hline Type of vehicle & Number of vehicles \\
\hline Passengers' cars & 283,613 \\
Trucks & 134,171 \\
Buses & 1,165 \\
Motorcycles & 136,782 \\
\hline
\end{tabular}

Source: various authors 


\section{Macrothink}

The quantities of gasoline and diesel oil used in conventional vehicles in Crete are presented in table 4.

Table 4. Gasoline and diesel oil use in conventional vehicles in Crete (2020)

\begin{tabular}{ll}
\hline Fuel & Quantity (tons/year) \\
\hline Gasoline & 123,634 \\
Diesel oil & 149,597 \\
Total & 273,231 \\
\hline
\end{tabular}

Source: various authors

Carbon emissions due to gasoline and diesel oil use in vehicles in Crete are presented in table 5 .

Table 5. Annual carbon emissions due to gasoline and diesel oil use in vehicles in Crete (2020)

\begin{tabular}{ll} 
Fuel & Annual $\mathrm{CO}_{2}$ emissions $\left(\mathrm{tnCO}_{2} /\right.$ year $)$ \\
\hline Gasoline $^{1}$ & 407,992 \\
Diesel oil $^{2}$ & 478,710 \\
Total & 886,702 \\
\hline
\end{tabular}

Source: own estimations, ${ }^{1} \mathrm{CO}_{2}$ emissions from gasoline $=3.3 \mathrm{kgCO} / \mathrm{kg},{ }^{2} \mathrm{CO}_{2}$ emissions from diesel oil $=3.2 \mathrm{kgCO} / \mathrm{kg}$

Taking into account that the population in Crete is at 623,100 inhabitants (You may find the information at the end of References section: www.statistics.gr) the annual carbon emissions per capita, due to vehicles' transportation, in 2020 was at $1.42 \mathrm{tnCO}_{2}$ per capita. This value corresponds at $23.36 \%$ of the country's $\mathrm{CO}_{2}$ emissions per capita in 2018 , at $6.08 \mathrm{tnCO}_{2}$, reported by the World Bank (You may find the information at the end of References section: https://data.worldbank.org).

\section{Mitigation of Carbon Emissions in Conventional Vehicles Equipped with ICEs}

Mitigation of carbon emissions in conventional vehicles equipped with ICEs can be achieved with the substitution of gasoline with bio-ethanol and diesel oil with bio-diesel. Carbon emissions can be also reduced or eliminated with the use of electric vehicles equipped either with re-chargeable batteries or with fuel cells. Electricity for re-charging the batteries should be generated by REs while the $\mathrm{H}_{2}$ used in fuel cells should be green electrolytic $\mathrm{H}_{2}$. Use of electric vehicles in Crete requires new infrastructure, concerning the creation of many installations for re-charging electric batteries, that is not available today in the island. 
Bio-fuels currently used in vehicles are mainly first generation bio-ethanol and bio-diesel. First generation bio-ethanol is produced by fermentation of sugars while first generation bio-diesel is produced by transesterification of oil crops, animal fat and used cooking oil (Jeswani et al, 2020, Rodionova et al, 2016). Efforts are being made for mass production of second generation bio-fuels including bio-ethanol and bio-diesel produced from lingo-cellulosic materials with non-conventional technologies as well as with conventional technologies based on novel starch, oil and sugar crops. Sugar beet and wheat are currently used in Europe for bio-ethanol production while rape seed for bio-diesel production. Substitution of petroleum-based fuels with bio-fuels in vehicles results in significant reduction of GHG emissions (Energy and Greenhouse gas balance of bio-fuels for Europe an update, 2002).

\section{Quantities of Bio-fuels Required for Substituting Conventional Fuels in Vehicles in Crete}

\subsection{Quantities of Bio-ethanol and Bio-diesel}

According to the EU goal regarding the share of bio-fuels in the total consumption of fuels in vehicles, at $14 \%$ in 2030, significant amounts of gasoline and diesel oil currently used in vehicles in Crete should be substituted with bio-fuels until the end of the current decade. In the current study only first generation bio-fuels currently produced in Europe have been considered. These include bio-ethanol produced from sugar beet and bio-diesel produced by oilseed rape. Currently sugar beet and oilseed rape are not cultivated in Crete while bio-ethanol and bio-diesel are not produced in the island. In the past the use of the carob fruit growing in Crete, that is rich in sugars, has been investigated for bio-ethanol production but the process is not economically viable since the annual quantity of carob fruit produced in Crete is low (Vourdoubas, 2002). Production of bio-diesel from fried vegetable oils in Crete has been also investigated (Vourdoubas, 2002). Although tourism industry is growing in the island the quantities of fried vegetable oils produced are low and they do not justify their processing in large plants for bio-diesel production. Taking into account the extensive cultivation of olive trees in the island production of second generation bio-fuels based on olive tree pruning and olive kernel wood could be a viable option in the future. However, in the current study, this possibility was not examined since there are not many similar commercial processes worldwide. Taking into account the energy content of gasoline, diesel oil, ethanol and bio-diesel the amounts of the required bio-fuels in vehicles in Crete for achieving the EU goal for 2030 are presented in table 6. 


\section{Macrothink}

Journal of Agricultural Studies

ISSN 2166-0379

2021, Vol. 9, No. 4

Table 6. Bio-fuels required for substituting $14 \%$ of petroleum-based fuels in vehicles in Crete (2020)

\begin{tabular}{lll}
\hline Fuel & Quantity (tons/year) & Carbon emissions (tnCO $/$ year) \\
\hline $\begin{array}{l}14 \% \text { of the gasoline } \\
\text { currently used }\end{array}$ & 57,309 & - \\
$\begin{array}{l}\text { Bio-ethanol replacing } 14 \% \\
\text { of the gasoline used }\end{array}$ & 29,709 & 67,019 \\
$\begin{array}{l}14 \% \text { of the diesel oil } \\
\text { currently used }\end{array}$ & 20,944 & \\
$\begin{array}{l}\text { Bio-diesel replacing } 14 \% \\
\text { of the diesel oil used }\end{array}$ & 24,802 & - \\
Total & - & 124,138 \\
\hline
\end{tabular}

Source: own estimations, Energy content $(M J / \mathrm{kg}):$ gasoline $=46$, ethanol=26.8, diesel oil $=45$, bio-diesel $=38$

\subsection{Energy and GHG Savings due to Future Use of Bio-fuels in Vehicles in Crete}

Substituting petroleum-based vehicle's fuels in Crete with bio-fuels results in energy savings. Energy saving is estimated by subtracting the energy required for producing the bio-fuel from its energy content plus the energy consumed during the production of petroleum-based fuel. Energy savings are higher in the case of utilizing the byproducts during bio-fuels production as animal feed. The GHG balance is calculated with the same way comparing the net GHG emissions incurred in producing the bio-fuel and the GHG emitted during burning an amount of petroleum-based fuel with the same energy content. GHG savings are also higher in the case of utilizing the byproducts during bio-fuels production as animal feed. Carbon emissions during combustion of bio-fuels are not taken into account since it is considered that biomass utilization has carbon neutral impacts. Energy and GHG savings during bio-fuels utilization substituting petroleum-based vehicle's fuels are presented in table 7.

Table 7. Energy and GHG savings when bio-fuels are replacing petroleum-based fuels in vehicles

\begin{tabular}{lllll}
\hline Saving & Bio-ethanol & Bio-ethanol & Bio-diesel & Bio-diesel \\
\hline $\begin{array}{l}\text { Taking into account the use of } \\
\text { by-products as animal feed }\end{array}$ & Without & With & Without & With \\
$\begin{array}{l}\text { Energy saving (\%) } \\
\text { GHGs saving (\%) }\end{array}$ & 17 & 31 & 47 & 56 \\
& 26 & 37 & 53 & 58 \\
\hline
\end{tabular}

Source: Energy and GHG balance of bio-fuels in Europe, 2002 


\section{Estimation of the Necessary Land Area for Crops' Cultivation and Production of the Required Bio-fuels in Crete}

In order to estimate the necessary land area for crop's cultivation and production of the abovementioned amounts of bio-fuels the following assumptions have been made:

a) Sugar beet will be cultivated for the production of bio-ethanol and oilseed rape for the production of bio-diesel, and

b) The annual yield for bio-ethanol production from sugar beet is at 4 tons/ha (table 1) while the annual yield for bio-diesel production from oilseed rape is at 1 tons/ha (table 2).

The land area for cultivating the abovementioned crops and production of the required quantities of bio-fuels in Crete is presented in table 8.

Table 8. Land area for production of the required quantities of bio-fuels in Crete

\begin{tabular}{llll}
\hline Bio-fuel & $\begin{array}{l}\text { Required quantity } \\
\text { (tons/year) }\end{array}$ & Cultivated crop & $\begin{array}{l}\text { Land area for the cultivation of } \\
\text { the crop (ha) }\end{array}$ \\
\hline Bio-ethanol & 29,709 & Sugar beet & 7,427 \\
Bio-diesel & 24,802 & Oilseed rape & 24,802 \\
Total & 54,511 & & 32,229 \\
\hline
\end{tabular}

Source: own estimations

The estimated land area required for the cultivation of the abovementioned energy crops, at 32,229 ha, corresponds at $3.81 \%$ of Crete's total area, at 845,000 ha.

\section{Discussion}

Our results indicate that significant amounts of bio-fuels are required for achieving the EU goal regarding the share of bio-fuels in the total vehicle's fuel consumption by 2030 in Crete. The necessary land area for cultivating the crops producing the required quantities of bio-ethanol and bio-diesel is not available in the island while sugar beet and rape seed crops have not been cultivated so far in Crete. Land use changes in Crete for cultivating energy crops could result in significant GHG emissions (Khanna et al, 2011). The required bio-fuels in Crete must be imported from other territories. Achieving carbon neutrality in the island of Crete in the next three decades, according to the EU goal for carbon neutrality by 2050, the replacement of the conventional vehicles in Crete with electric vehicles should be considered. Different options regarding de-carbonization of transportation in Crete include the use of electric vehicles with re-chargeable batteries, electric vehicles with fuel cells powered with green $\mathrm{H}_{2}$ and conventional vehicles equipped with ICEs using bio-fuels. These options should be investigated, compared and assessed. The abundance of solar and wind energy resources in Crete favors the local generation of green electricity and production of green electrolytic $\mathrm{H}_{2}$ required for powering electric vehicles. Therefore the "carbon free green fuels" powering electric vehicles can be easily produced in Crete, due to the endogenous renewable energy resources, while the bio-fuels required in conventional vehicles is rather 
difficult to be produced in the island. Our results indicate the quantities of bio-fuels needed and the necessary land resources required for their production while they do not indicate their cost as well as the advantages and drawbacks compared with other possible options for reducing the GHG emissions in vehicles in Crete. It is suggested that a comparative study should follow investigating various viable options regarding the use of different fuels in transportation in the island reducing or totally eliminating its carbon emissions in the long run.

\section{Conclusions}

The quantity of the petroleum-based fuels used annually in conventional vehicles in Crete has been estimated as well as the required bio-fuels for substituting $14 \%$ of them according to the EU target for 2030. The necessary land area for cultivating sugar beet and rape seed for the production of bio-fuels has been also calculated. The quantity of gasoline and diesel oil used in vehicles in Crete in 2020 was at 273,231 tons while their $\mathrm{CO}_{2}$ emissions were at 886,702 tons. For substituting $14 \%$ of the gasoline and diesel oil used in Crete in 2020 29,709 tons of bio-ethanol and 24,802 tons of bio-diesel are required. The necessary land area for sugar beet cultivation and production of the abovementioned quantity of bio-ethanol has been estimated at 7,427 ha. The necessary land area for rape seed cultivation and production of the abovementioned quantity of bio-diesel has been estimated at 24,802 ha. The total necessary land area, at 32,229 ha, corresponds at 3.81\% of island's area. The results could be useful to policy makers in Crete who design the appropriate policy measures for complying with the EU target regarding the share of bio-fuels in total vehicles' fuels consumption by 2030. They are also useful in assessing different options for de-carbonizing the transportation sector in Crete comparing the use of bio-fuels in conventional vehicles with electric vehicles equipped either with re-chargeable batteries or with fuel cells powered by renewable electricity and green $\mathrm{H}_{2}$. They can be also used for the creation of the clean energy transition plan in Crete complying with the EU target for eliminating the net GHG emissions by 2050. The cultivation of energy crops in Crete for bio-fuels production is not foreseen in the future and the required bio-fuels should be imported from other territories. Future work should be focused in the assessment of different options for de-carbonizing the transportation sector in the island comparing a) substitution of fossil fuels used in conventional vehicles in Crete with bio-fuels, b) use of electric vehicles equipped with re-chargeable batteries powered by renewable electricity, and c) use of electric vehicles equipped with fuel cells powered by green electrolytic $\mathrm{H}_{2}$.

\section{References}

Ajanovic, A. (2010). Bio-fuels versus food production: Does bio-fuels production increase food prices? Energy, 1-7. https://doi.org/10.1016/j.energy.2010.05.019

Bessou, C., Ferchaud, F., Gabrielle, B., \& Mary, B. (2010). Bio-fuels, greenhouse gases and climate change. A review, Agronomy for Sustainable Development. Springer Verlag/EDP Sciences/INRA, 2009, pp.1-79. https://doi.org/10.1051/agro/2009039. cirad-00749753

Beschkov, V. (2017). Biogas, bio-diesel and bio-ethanol as multifunctional renewable fuels and raw materials, Chapter 10, Frontiers in Bio-energy and Bio-fuels, 185-205.

Bio-fuels - a solution for climate change, 1999. USA Department of Energy. Retrieved at 
3/9/2021 from https://www.nrel.gov/docs/fy99osti/24052.pdf

Chen, H., \& Chen, G. Q. (2011). Energy cost of rapeseed-based bio-diesel as alternative energy in China, Renewable Energy, 36, 1374-1378.

https://doi.org/10.1016/j.renene.2010.11.026

Energy and Greenhouse gas balance of bio-fuels for Europe- an update, 2002. CONCAWE. Retrieve at 3/9/2021 from

https://www.concawe.eu/wp-content/uploads/2017/01/2002-00213-01-e.pdf

Ethanol internal combustion engines, IEA Energy technology systems analysis program, Technology Brief T06, 2010. Retrieved at 3/9/2021 from https://iea-etsap.org/E-TechDS/PDF/T06_Ethanol\%20ICEs_final_18Jun10_GS_OK_NH.pdf

EU Directive 2018/2001 on the promotion of the use of energy form renewable sources. Retrieved at 3/9/2021 from

https://www.europeansources.info/record/directive-eu-2018-2001-on-the-promotion-of-the-us e-of-energy-from-renewable-sources/

Ewing, M., \& Msangi, S. (2009). Bio-fuels production in developing countries: assessing tradeoffs in welfare and food security, Environmental Science and Policy, 12, 520-528. https://doi.org/10.1016/j.envsci.2008.10.002

Huang, W. D., \& Percival Zhang, Y. H. (2011). Energy efficiency analysis: Biomass to wheel efficiency related with bio-fuels production, fuel distribution and power train systems, PLoS one, 6(7), e22113. https://doi.org/10.1371/journal.pone.0022113

Huseyin, O. H. (2014). Energy analysis for bio-diesel production from rapeseed oil, Energy Exploration and Exploitation, 32(6), 1005-1031.

Jeswani, H. K., Chilvers, A., \& Azapagic, A. (2020). Environmental sustainability of bio-fuels: a review, Proceedings of Royal Society A, 476, 20200351.

https://doi.org/10.1098/rspa.2020.0351

Khanna, M., Crago, C. L., \& Black, M. (2011). Can bio-fuels be a solution to climate change? The implications of land use change-related emissions for policy, Interface Focus, 1, 233-247. https://doi.org/10.1098/rsfs.2010.0016

Kumar, M. A., Misra, V., Santeshwari, P. A. D., \& Srivastava, S. (2021). Sugar beet cultivation in India: Prospects for bio-ethanol production and value-added co-products, Sugar Technology. https://doi.org/10.1007/s12355-021-01007-0

Langeveld, H., Van de Ven, G., De Vries, S., Ven de Brink, L., \& De Visser, C. (2008). Ethanol from sugar beet in the Netherlands: energy production and efficiency, in the $8^{\text {th }}$ European IFSA Symposium, 6-10 July 2008, Clermont-Ferrend, France.

Malode, S. J., Keerthi Prabhu, K., Mascarenhas, R. J., Shetti, N. P., \& Aninabhavi, T. M. (2021). Recent advances and viability in bio-fuel production, Energy Conversion and Management: X, 10. https://doi.org/10.1016/j.ecmx.2020.100070.

Mc Carthy, P., Rasul, M. G., \& Moazzem, S. (2011). Comparison of the performance and 
emissions of different bio-diesel blends against petroleum diesel, International Journal of Low Carbon Technologies, 6, 255-260. https://doi.org/10.1093/ijlct/ctr012

Molino, A., Larocca, V., Chianese, S., \& Musmarra, D. (2018). Bio-fuels production by biomass gasification: A review, Energies, 11, 811. https://doi.org/10.3390/en11040811

Ramachandram, S., \& Stimming, U. (2015). Well to wheel analysis of low carbon alternatives for road traffic, Energy and Environmental Research, 8, 3313.

https://doi.org/10.1039/C5EE01512J

Rodionova, M. V., Poudyal, R. S., Tiwari, I., Voloshin, R. A., Zharmukhamedov, S. K., Nam, H. G., ... Allakhverdiev, S. I. (2017). Bio-fuel production: Challenges and opportunities, International Journal of Hydrogen Energy, 42(12), 8450-8461.

https://doi.org/10.1016/j.ijhydene.2016.11.125

To, H., \& Quentin, G. R. (2015). Oil prices, bio-fuels production and food security: past trends and future challenges, Food Security, 7(2), 323-336.

https://doi.org/10.1007/s12571-015-0438-9

Vourdoubas, J. (2002). Efforts for the production of liquid biofuels in Crete: bioethanol and biodiesel. In: Rozakis S., \& Sourie J-C. (eds), Comprehensive economic and spatial bio-energy modelling, (pp. 151-157). Options Méditerranéennes: Série A. Séminaires Méditerranéens; n. 48.

Vourdoubas, J. (2018). Studies on the electrification of the transport sector in the island of Crete, Greece, Open Journal of Energy Efficiency, 7, 19-32. https://doi.org/10.4236/ojee.2018.71002

Vourdoubas, J. (2021). Renewable energies use for hydrogen production powering fuel cell vehicles in the island of Crete, Greece, American Scientific Journal for Engineering Technology and Sciences, 75(1), 106-120.

Water implications of bio-fuels production in the United States, 2007. Report in Brief, The National Academy of Science, USA. Retrieved at 3/9/2021 from https://www.nap.edu/resource/12039/biofuels_brief_final.pdf

White paper on tank to wheel emissions of ethanol and bio-diesel powered vehicles as compared to petroleum alternatives, 2010, Center of Transportation Studies, University of Minnesota. $\quad$ Retrieved at $3 / 9 / 2010$ from file://C:/Users/User/AppData/Local/Temp/EPA-R09-OAR-2010-0717-0038_content.pdf

Zah, R., \& Ruddy, T. F. (2009). International trade of bio-fuels: an introduction to the special issue, Journal of Cleaner Production, 17, S1-S3. doi:10.1016/j.jclepro.2009.05.005

\section{Copyright Disclaimer}

Copyright for this article is retained by the author(s), with first publication rights granted to the journal.

This is an open-access article distributed under the terms and conditions of the Creative Commons Attribution license (http://creativecommons.org/licenses/by/4.0/). 